\title{
The Puzzling Behavior of Business Loans in the Current Recession
}

\author{
R. ALTON GILBERT
}

D

URING the current recession, the drop in U.S. economic activity has exceeded the average decline in prior postwar recessions (charts 1 and 2). Despite this sizable drop in real output, large commercial banks have increased substantially their loans to domestic business firms. Business loans at large commercial banks rose at an 18.6 percent annual rate from July 1981 through June 1982. There has been little net change in those loans since June $1982 .^{1}$ In contrast, business loans rose no more than about 3 percent above the peak month level during the other recessions shown in chart $3 .^{2}$

\footnotetext{
Authorization for U.S. banks to begin operation of intemationat barking facilites (IBFs) in December 1981 complicates analysis of growth in business loans at commercial banks in recent months. Some of the loans to non-U.S. addressees that had been reported as asset of U.S. domestic offtces of commercial banks have beer shifted to their IBFs, thus reducing the anount of loans included in the series on business loans by U.S. offices of commerciat banks. Such a bias is eliminated from the business loan data used in this article by subtracting from total business loans by large, weekly reporting banks their loans to non-U.S. addressees. The breakdown in the data between loans to U.S. addressees and nom-U.S. addressees of weekly reporting banks begins in 1979. Dataz on business loans before 1979 used in this article are total business loans of weekly reporting banks.

${ }^{2}$ With one exception, recession periods are those specified by the National Bureau of Economic Research. The National Burea indicates that one recession began after November 1973 and ended in Match 1975. The decline in econome activity from late 1973 through early 1975 had two distinct phases. In the first phase from late 1973 through about September 1974, the decine in economic: activity reflected primarily the effects of a reduction in the supply of oil. Beginning in the fall of 1974 , economic indicators reflected the nore usual symptoms of a dechne in economic activity due to a slowing in growth of aggregate denand. Since the objective of comparisons across recession periods is to determine the usuat patferns of variolss series when there is a slowing in growth of aggregate demand, September 1974 is considered the peak month of that recession, with March 1975 the trough month. For an analysis of this recession, see Norman N. Bowsher, "Two Stages to the Current Recession," this Review (Jne 1975), pp. 248 .
}

Some analysts claim that the rapid growth of business loans during this recession reflects an increase in the total funds raised by businesses to alleviate their financial distress and, therefore, provides further evidence of the severity of the current recession. Other explanations for the rapid growth of business loans by commercial banks also suggest a rapid expansion of total funds raised by firms in the nonfinancial business sector, prompted by various other causes. This article investigates whether these explanations are accurate;

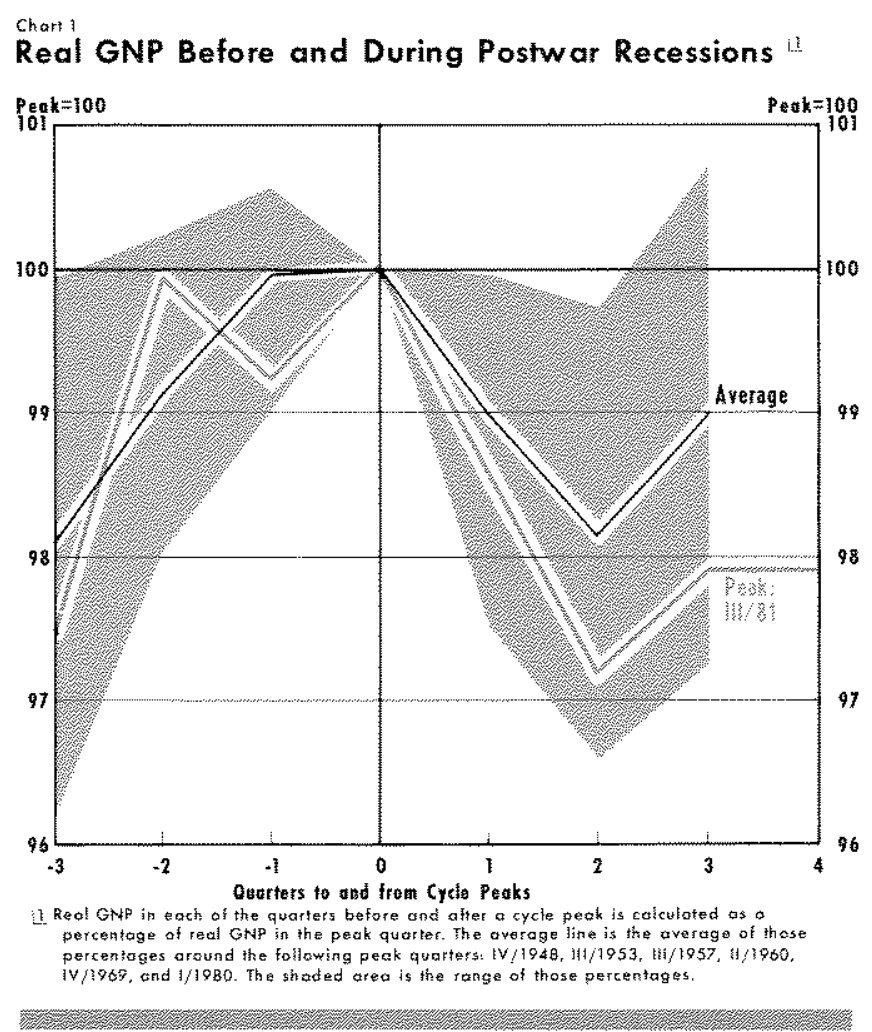




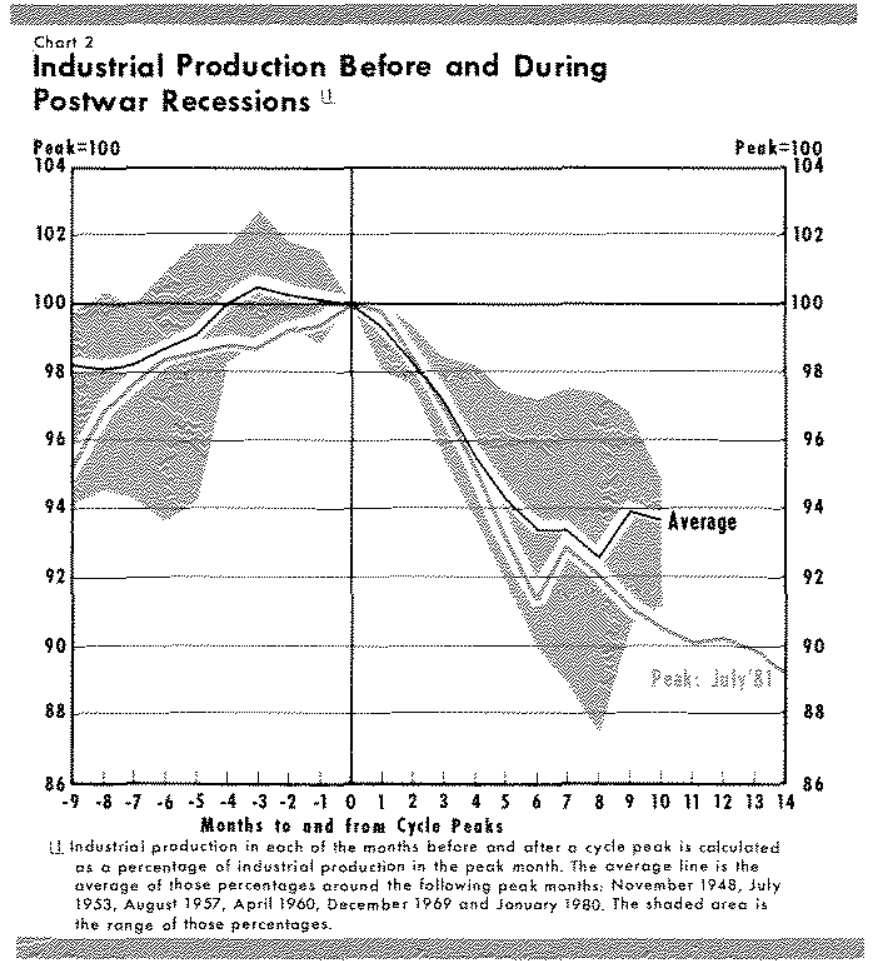

that is, whether the total funds raised by nonfinancial business firms, in fact, have increased at an unusually rapid rate during this recession. The evidence presented here does not support these explanations for the growth in bank loans to business firms. The aspect of business finance that is unusual in the current recession is not the amount of total funds raised, but the relatively large share of funds raised from short-term sources, including bank loans, and the small share from long-term sources.

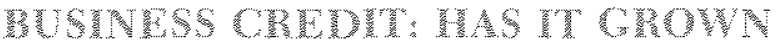

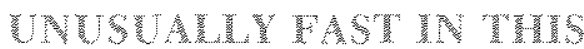 MCOSGOM}

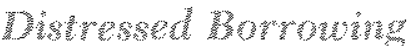

Several analysts have atributed the unusually rapid growth of business loans at commercial banks to the financial distress of business firms. They cham that nonfinancial firms have been borrowing heavily to offset the effects of declining profits. ${ }^{3}$ Evidence of financial distress does exist in that before-tax profits of firms in the nonfinancial corporate sector have fallen more rapidly during the current recession period than during comparable periods in most other postwar recessions (table 1).

\footnotetext{
3"What Has Fired Up the Paper Market." Business Week one 2l. 1982), p. 112
}

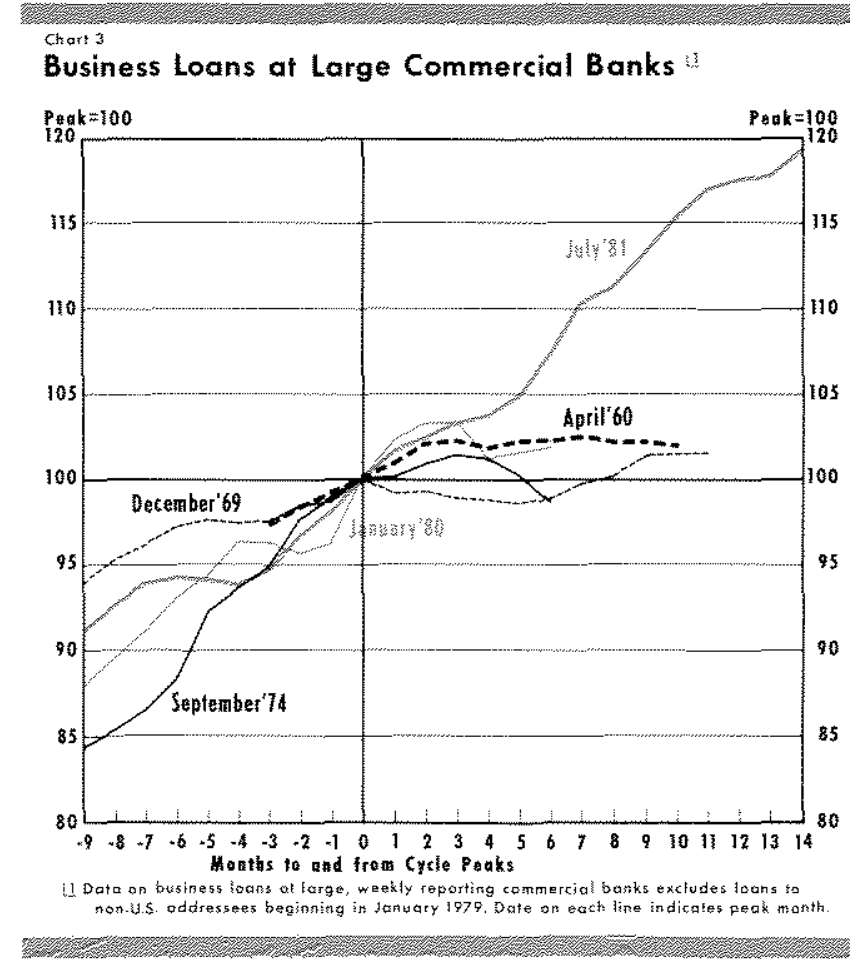

There is a problem with such evidence, however. Increases in depreciation charges against taxable in come allowed under the Economic Recovery Act of 1981 have reduced prewtax profits, but have increased the firms' cash flow. A more relevant measure of funds generated by businesses from their operations is U.S. internal funds, which equal profits after taxes, less dividends, plus depreciation charges. The percentage decline in internally generated funds during the current recession is about average for postwar recession periods (table 2). Therefore, the data do not support the contention that frms have increased their borrowing to offset declines in internally generated funds.

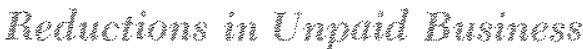 woone raxes}

Another explanation that has been offered for the rapid grow th of business loans involves the response of businesses to an increase in the penalty interest rate on umpaid tax liabilities. Effective in early 1982, the penalty interest rate on delinquent income taxes of business firms was increased from 12 percent to 20 percent per year. Businesses with tax liabilities subject to the 20 percent penalty rate could reduce their costs by borrowing at any interest rate below 20 percent to reduce their delinquent income taxes. ${ }^{4}$

\footnotetext{
"John D. Panlus, "Role of Corponate Tax Paments in Recent ShortTerm Business Borrowing, Goldman Sachs' Economic Resenth Unoe 7,1982 .
} 


\section{Table 1}

\begin{tabular}{|c|c|c|c|}
\hline \multirow[b]{2}{*}{$\begin{array}{l}\text { Peak } \\
\text { quarter }\end{array}$} & \multicolumn{3}{|c|}{ Fate of change from peak quarter to } \\
\hline & $\begin{array}{l}\text { One } \\
\text { cuarter } \\
\text { later }\end{array}$ & $\begin{array}{l}\text { Two } \\
\text { quarters } \\
\text { later }\end{array}$ & $\begin{array}{l}\text { Thiee } \\
\text { quarters } \\
\text { later }\end{array}$ \\
\hline 1111953 & $69.5 \%$ & $4355 \%$ & $21.6 \%$ \\
\hline $11 / 1957$ & $=34.3$ & 44,9 & 307 \\
\hline 111960 & -18.1 & -20.7 & 418.0 \\
\hline N/1969 & (37. & -221 & 142 \\
\hline 1119974 & -324 & 442 & 215 \\
\hline U/1980 & 629 & 49.2 & -6.6 \\
\hline $\begin{array}{l}\text { Average of } \\
\text { above }\end{array}$ & 4.424 & -31.1 & 188 \\
\hline $1 / 1 / 1981$ & -37.3 & 50.4 & -39.5 \\
\hline
\end{tabular}

Compounded annual rates seasonaly adjusted.

Table 2

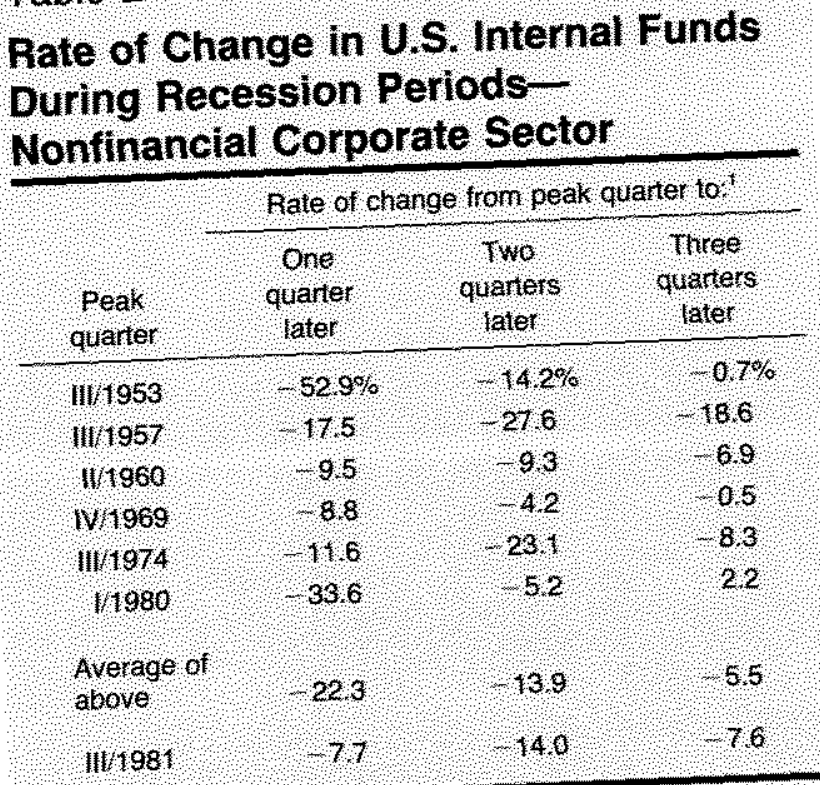

TCompounded annual ates, seasonally adjusted
Table 3

Profit Tax Payments Less Profit Tax Accruals-Nonfinancial Corporate Sector (billions of dollars) ${ }^{4}$

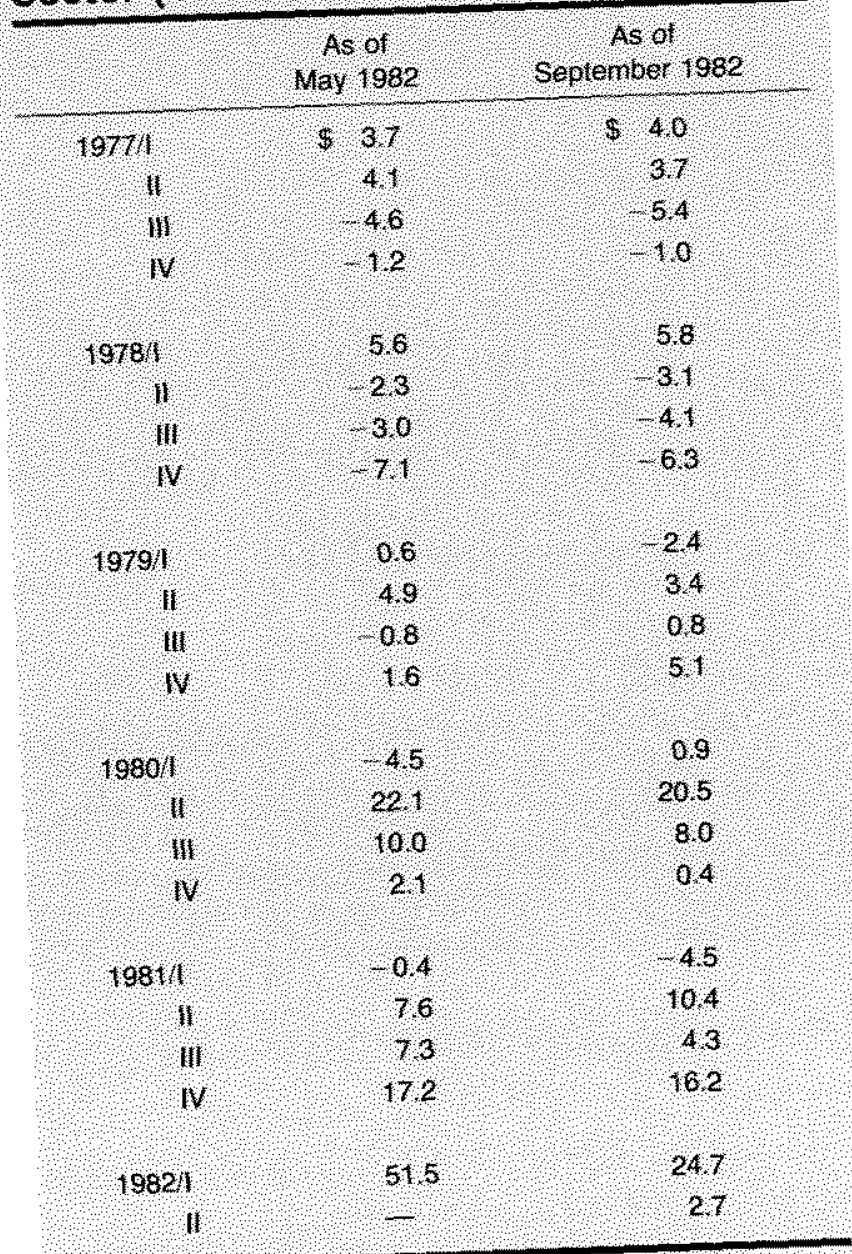

Seasonally adjusted annual rates.

According to the flow of funds data released in May 1982, the difference between income tax payments by firms in the nonfinancial corporate sector and their accrued tax habilities (at seasonally adjusted annual rates) was unusually large in $\mathrm{V} 1982$ (table 3). This measure indicates the amount by which current tax payments exceed (or fall below) the tax liabilities incurred on current income. Revised data indicate that the difference between income tax payments and tax accruals was substantially smaller in $1 / 1982$ than indicated earlier, and that the amount by which tax payments exceeded accruals was relatively small in II 1982. Tax payments exceeded accrued income taxes by 


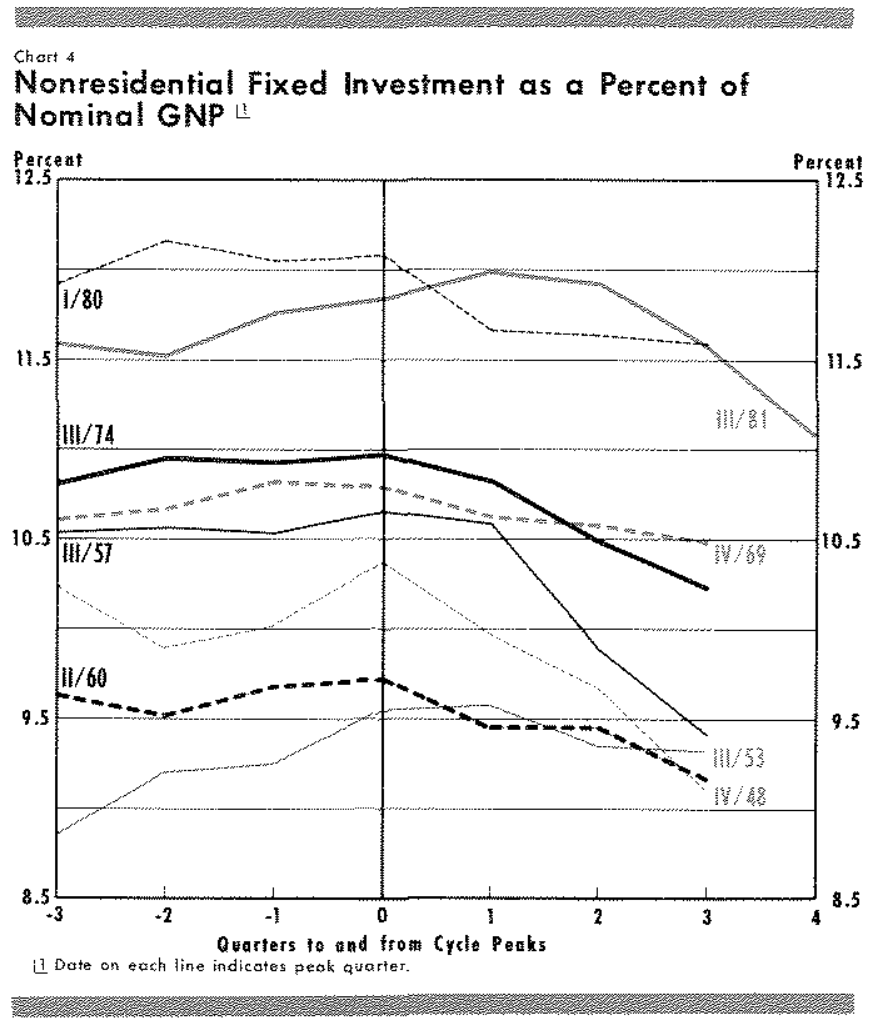

$\$ 5.8$ billion in III/1982, a difference that is not large relative to other quarters. Business income tax payments, therefore, do not appear to be an important factor in explaining business demand for credit.

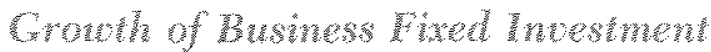

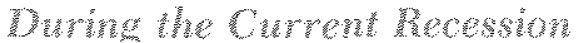

Business fixed investment as a proportion of total spending generally falls sharply throughout recession periods. This cyclical pattern was delayed in the current recession antil the second and third quarters of this year (chart 4). Nonresidential fixed investment as a percentage of nominal GNP was higher during the first two quarters of the current recession than at the cycle peak, whereas that ratio was below that of the peak quarter by the second quarters of other postwar recession periods.

The relatively large proportion of business fixed investment to total spending through the first quarter of this year appears to reflect a response to new incentives for investment in the Economic Recovery Act of $1981 .{ }^{5}$ Besides increasing tax incentives for in-

Jane G. Gravelle, "Effects of the 1981 Depreciation Revisions on the Taxation of Incone from Business Capital, National Tar Journal (Mardı 1982), pp. 1-20.
Table 4

Rate of Change in Fixed Investment plus Inventory InvestmentNonfinancial Corporate Sector ${ }^{1}$

\begin{tabular}{|c|c|c|c|}
\hline \multirow[b]{2}{*}{ peak } & \multicolumn{3}{|c|}{ Rate of change from peak quarter to 2} \\
\hline & $\begin{array}{l}\text { One } \\
\text { quater } \\
\text { later }\end{array}$ & $\begin{array}{l}\text { Two } \\
\text { quarters } \\
\text { tater }\end{array}$ & $\begin{array}{l}\text { Three } \\
\text { guarters } \\
\text { tater }\end{array}$ \\
\hline $11 / 1953$ & $654 \%$ & $35.6 \%$ & $220 \%$ \\
\hline $11 / 1957$ & 52.6 & 54.4 & 439 \\
\hline $11 / 960$ & 156 & 351 & 130 \\
\hline U/1969 & 240 & 32 & 24 \\
\hline 11974 & 653 & 360 & 278 \\
\hline 11980 & 24.5 & -176 & 35 \\
\hline 111981 & -243 & 278 & 16.5 \\
\hline
\end{tabular}

vestment, that act also provides investment incentives for firms with no taxable income through leasing arrangements with other firms that earn taxable income. Under such an arrangement, a profitable firm purchases the plant or equipment, charges the tax credits against its federal income tax, and leases the plant or equipment to a firm that currently has no taxable income. This tax-leasing provision may have altered the cyclical response of business investment to tax incentives.

Several studies have found positive effects of tax incentives on business investment. The response is especially large if the tax incentives are considered temporary. ${ }^{6}$ The debate in Congress concerning options to reduce the federal budget deficit may have made the tax incentives for business investment appear to be only temporary.

The unusual strength of business fixed investment during the current recession does not explain the rapid growth of borrowing by business firms from commercial banks. Business fixed investment plus inventory investment actually declined during the current reces-

\footnotetext{
"Martin Feldstein, "Inflation, Tax Rules and Investment: Some Econometric Evidence," Econometrica (July 1982), pp. 825-62; and Lawrence H. Summers, "Tax Policy and Corporate Invest" ment," in Lanrence H. Meyer, ed., The Supply-Side Effects of Economic Policy. conference cosponsored by the Federal Reserve Bank of St. Louis and the Center for the Study of American Business, Washington Eniversity, October 24-25, 1980, pp. 1.1548 .
} 


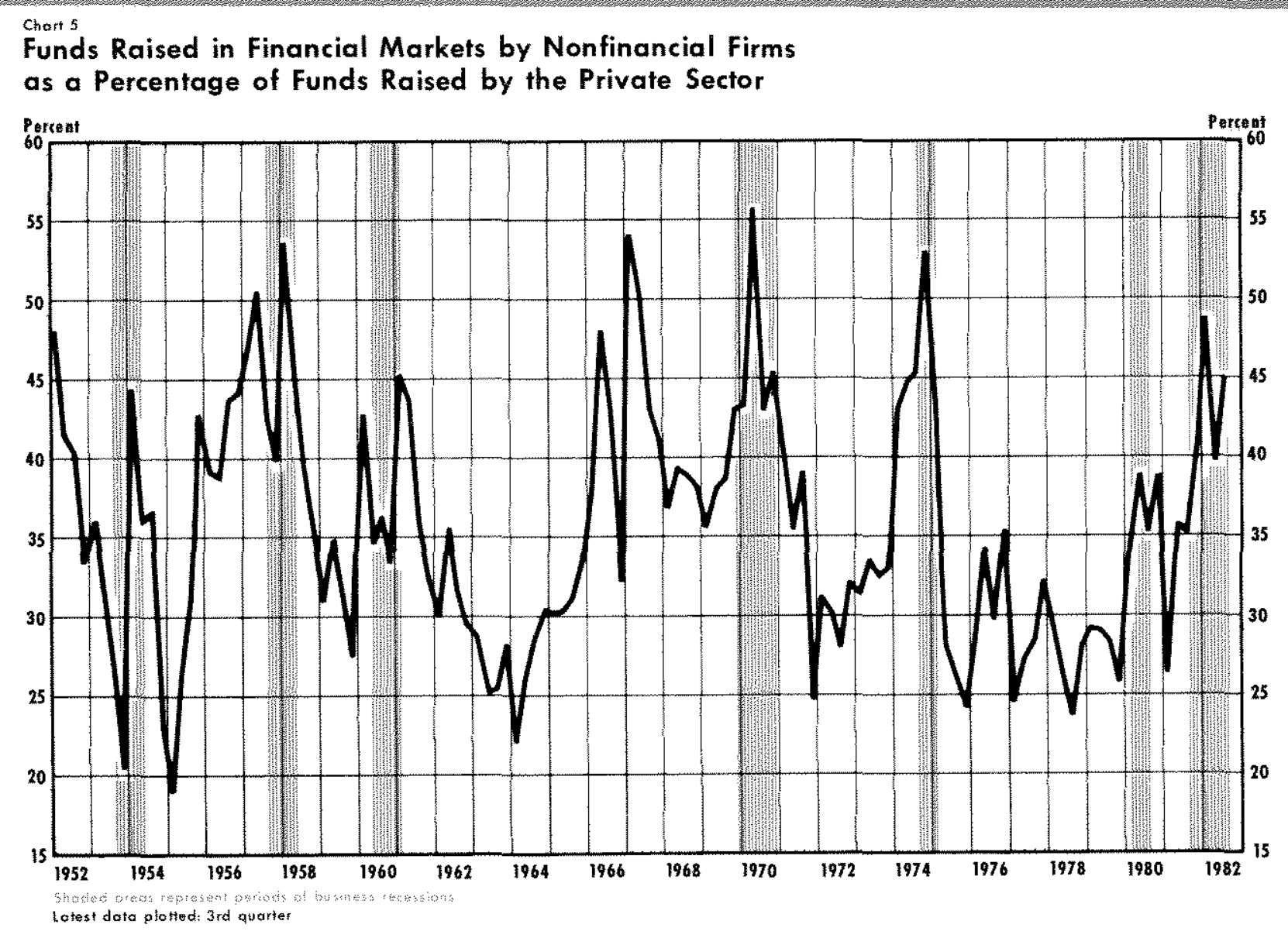

sion at rates comparable to the declines in prior recessions (table 4). Thus, the sharp decline in business inventory investment more than offset the growth of fixed investment.

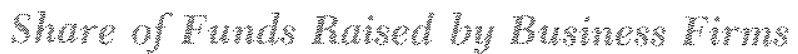

The issue of whether business firms have been raising funds at rates that are typical for a recession period can be investigated directly by examining the total funds raised by the nonfinancial corporate sector relative to the funds raised by the entire private sector, The share of funds raised by nonfinancial firms tends to rise during recession periods (chart 5). Thus, the increase in the share of funds raised by business firms during the current recession is typical of the pattern in previous recession periods.

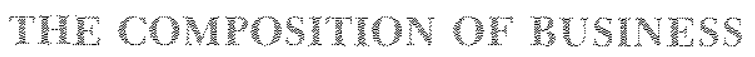

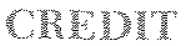

The rapid growth of business loans at commercial banks during the current recession is unusual. The possible explanations cited above all suggest that the growth of total funds raised by business firms should be rapid, yet this is not the case. The share of funds business firms raised by borrowing from commercial banks, therefore, must have been unusually large dur" ing the current recession, with relatively small shares of funds raised from other sources.

The growth of business loans at commercial banks has not been accompanied by a decline in commercial paper outstanding. Business loans at large commercial banks plus commercial paper outstanding issued by nonfinancial firms have risen more rapidly during the current recession than in the two previous recessions (chart 6).

The share of funds raised by nonfinancial firms from long-term sources has been unusually low during the current recession. Businesses raised funds during previous recessions primarily by issuing equities, bonds and mortgages, and actually reduced short-term debt in some periods (indicated by the ratio in chart 7 above unity). The share of funds raised from these long-term sources has increased in each quarter of the current 
Chart 6

Business Loans at Large Commercial Banks plus Nonfinancial Commercial Paper ${ }^{4}$

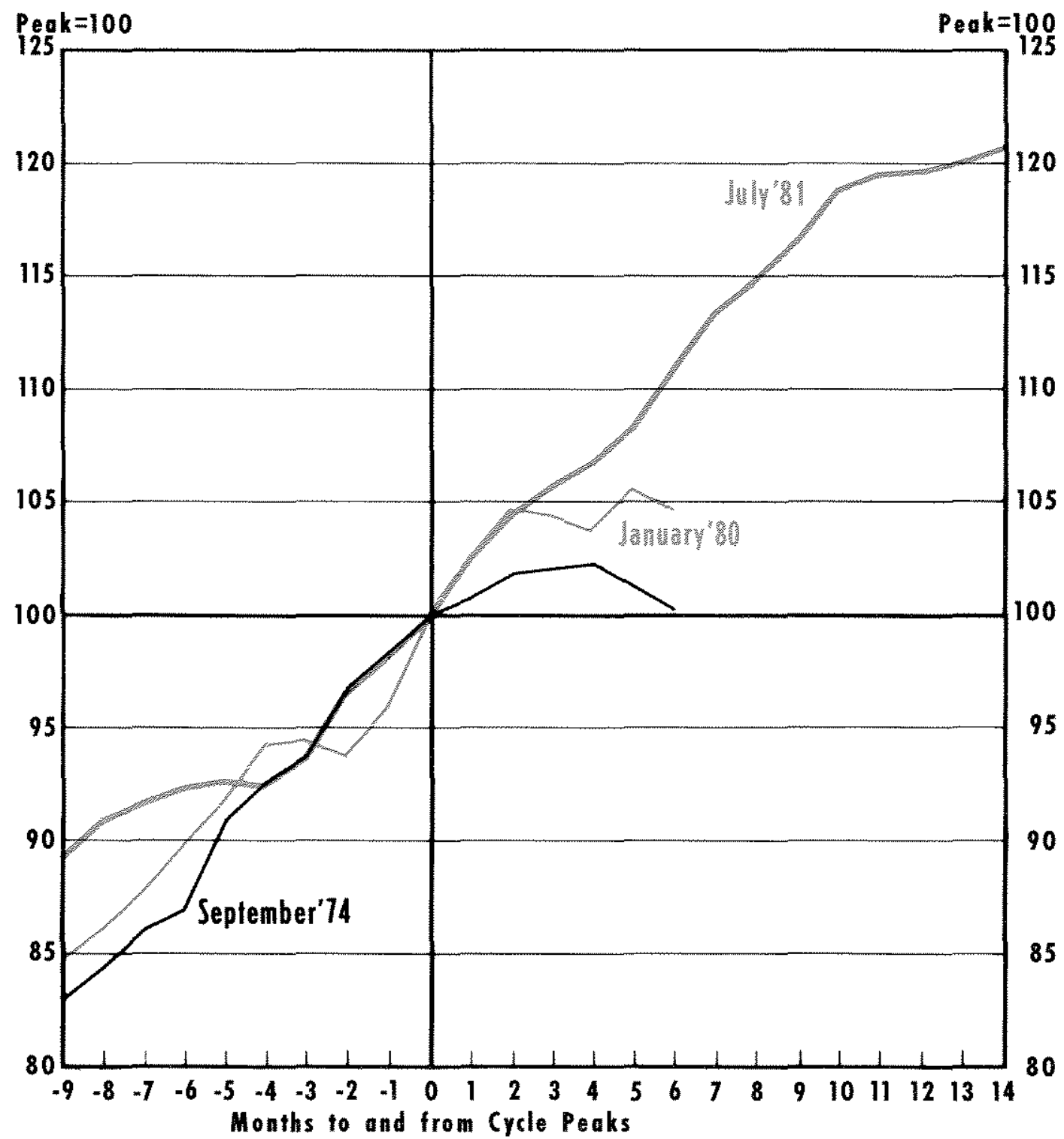

1 Data on business loans at large, weekly reporting commercial banks excludes loans to non-U.S. addressees beginning in January 1979. Date on each line indicates peak month.

recession from just above zero in III/1981. As of $\mathrm{II} /$ 1982, that share was only about 35 percent, substantially below the proportion of funds businesses raised from long-term sources during comparable periods after prior cycle peaks. ${ }^{\overline{ }}$ In III/1982, however, the share of funds raised from long-term sources increased to

\footnotetext{
The dollar magnitude of funds raised from short-term sources by nonfinancial corporate business during the three quartens ending
}

II/1982 is comparable to the dollar manitude of the rise in business foans by large commercial banks plus nonfinancial commercial paper over the same period. Nonfinancial corporate business raised abot $\$ 75.2$ billion in the fonmeial markets during those three quarters, with $\$ 18.8$ billion from long-term sources, leaving a difference of $\$ 56.4$ billion. Business loans at large commercial banks plus nonfinancial commercial paper (monseasonally adjusted) rose by $\$ 36$ billion from III/1981 to $1 / / 1982$. The difference between the $\$ 56$. 4 billion and $\$ 36$ billion is accomted for by business toans from other banks and other sources of short-kerm credit for ronfinancial business firns. 


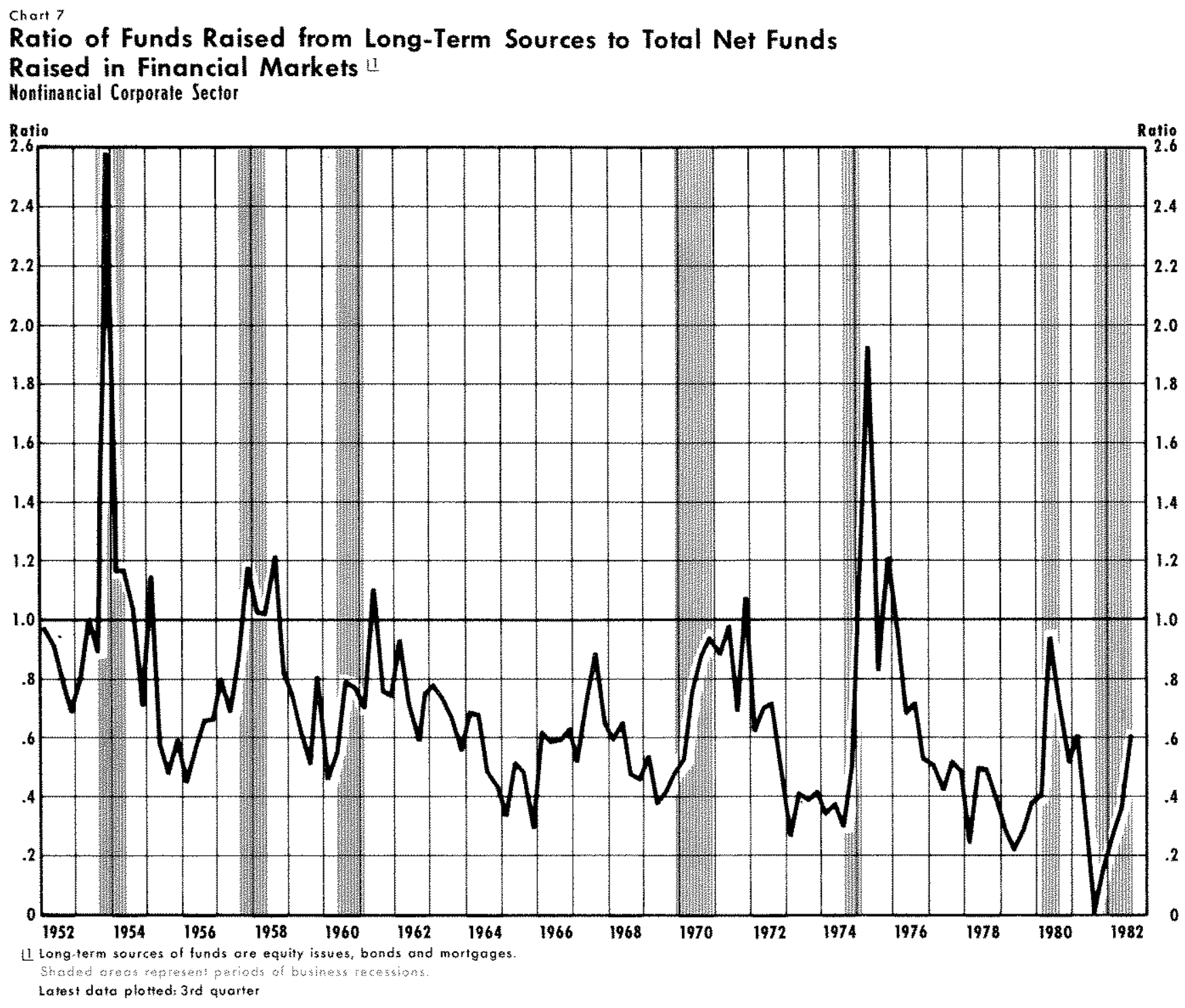

about 60 percent, and the growth of business loans by large commercial banks slowed sharply. Thus, the maturity distribution of funds raised by firms in the nonfinancial corporate sector in III/1982 was more typical of prior recessions than of the current recession.

This article does not provide an explanation for the relatively limited amount of long-term financing by nonfinancial firms during most of the current recession. None of the reasons cited at the start of this article is adequate for this purpose. Similarly, a comparison of the patterns of long-term and short-term interest rates over the current and past recession periods does not indicate why the share of funds raised from longterm sources should be different during the current recession. During prior recessions, the yield on corporate Aaa rated bonds was stable relative to the wider movements in the yield on four-to-six-month prime commercial paper, and this short-term rate declined relative to the long-term rate during the recession periods (chart 8).

Thus, businesses increased the share of funds they raised from long-term sources during the past recessions, despite the decline in short-term interest rates relative to long-term rates. The pattern of short-term and long-term interest rates during the current recession has been similar to that of previous recessions, but during the current recession prior to III/1982, businesses did not shift to long-term sources of finance as they did during earlier recession periods. 


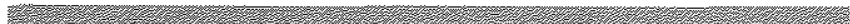

Chapt a

Pattern of Long-Term and Short-Term Interest Rates

During Recession Periods
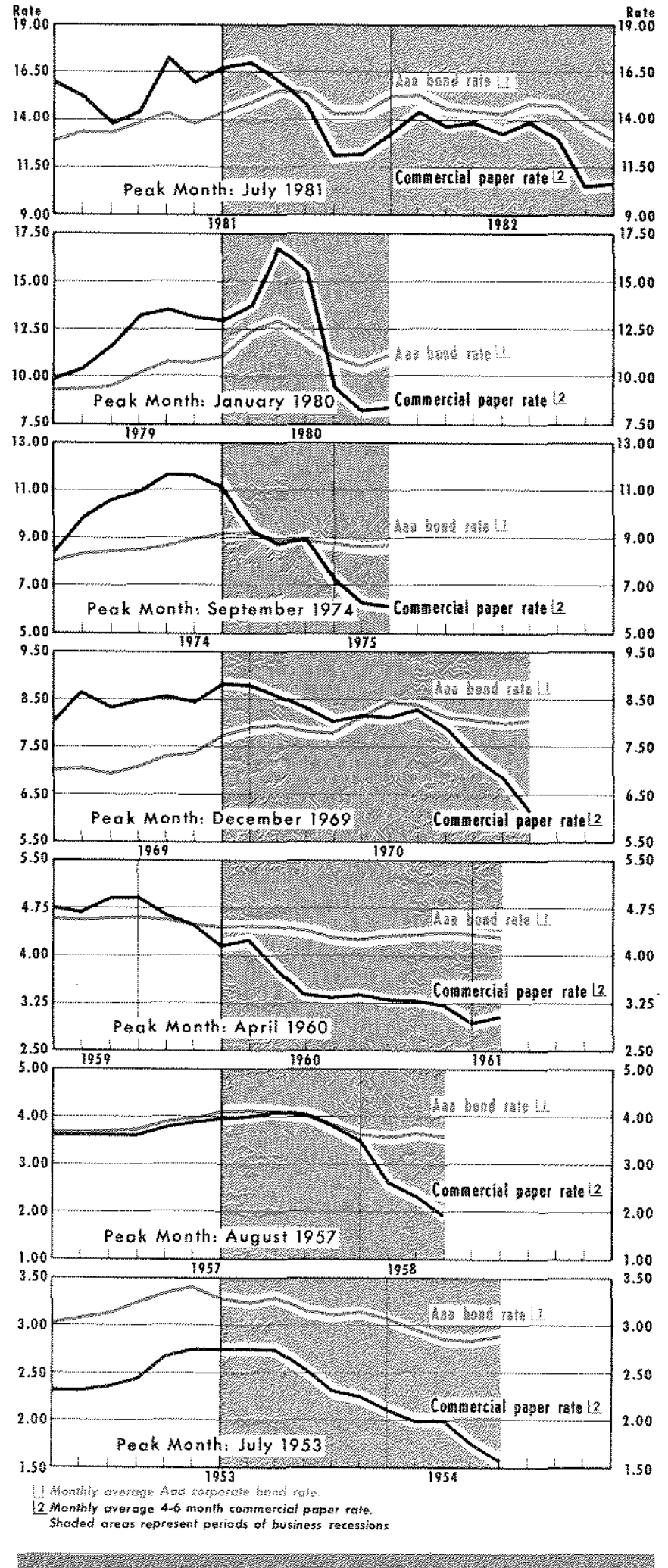

\section{CONCUSTONS}

Loans to domestic business firms by large commercial banks have risen rapidly during the current recession. Some analysts have claimed that business credit demand has been unusually strong as a consequence of the unusually weak economy. Total funds raised by business firms, however, have not increased at an unusually rapid rate during the current recession. The unusual aspect of business finance during the current recession has been a relatively low proportion of funds raised from long-term sources, including bonds, equities and mortgages. This relatively low share of funds raised from long-term sources has been accompanied by rapid growth of short-term business credit, including loans from large commercial banks. 